\title{
ESTIMASI INTENSITAS GEMPA BUMI DAN PERCEPATAN TANAH MAKSIMUM KOTA PADANG BERDASARKAN DATA HISTORIS GEMPA 1976 - 2016 DI WILAYAH MENTAWAI
}

\author{
Dwi Pujiastuti' ${ }^{1}$, Rido Nofaslah ${ }^{1}$, Arif Budiman ${ }^{1}$ \\ ${ }^{1}$ Laboratorium Fisika Bumi Jurusan Fisika Universitas Andalas \\ e-mail : Dwi_Pujiastuti@yahoo.com
}

\begin{abstract}
ABSTRAK
Telah dilakukan estimasi nilai intensitas gempa bumi dan percepatan tanah maksimum di Kota Padang berdasarkan data historis gempa 1976-2016 di wilayah Mentawai. Rumusan empiris $\mathrm{Si}$ and Midorikawa (1999) digunakan untuk menghitung percepatan tanah maksimum dan rumusan empiris Murphy O'Brein untuk menghitung intensitas gempa. Data yang digunakan diperoleh dari USGS untuk gempa di wilayah Mentawai dengan dengan kekuatan $\geq 5$ SR dan kedalaman $\leq 70$ $\mathrm{km}$ dari tahun 1976 - 2016. Daerah penelitian dibatasi oleh $1.1^{\circ} \mathrm{LS}-0,4^{\circ} \mathrm{LU}$ dan $100,05^{\circ} \mathrm{BT}-$ $100,35^{\circ}$ BT yang dibagi dengan jarak grid 0,02 $2^{\circ}$ sehingga didapatkan 208 titik penghitungan. Intensitas gempa dan percepatan tanah maksimum dihitung berdasarkan data gempa di wilayah intraplate dan interplate. Dari hasil pengolahan data didapatkan peta percepatan tanah maksimum dan intensitas gempa Kota Padang dari kedua wilayah gempa tersebut.. Nilai percepatan tanah maksimum terbesar di Kota Padang akibat gempa di wilayah interplate segmen Mentawai berkisar antara $57,89 \mathrm{~cm} / \mathrm{s}^{2}$ sampai $119,69 \mathrm{~cm} / \mathrm{s}^{2}$. Kecamatan dengan percepatan tanah maksimum akibat gempa di wilayah interplate adalah Kecamatan Bungus Teluk Kabung yaitu berkisar antara 106,21 $\mathrm{cm} / \mathrm{s}^{2}$ sampai 119,69 cm/ $/ \mathrm{s}^{2}$ dengan intensitas gempa sebesar VI - VII MMI. Nilai percepatan tanah maksimum di Kota Padang akibat gempa di segmen intraplate wilayah Mentawai berkisar antara sebesar 830,38 cm/s $/ \mathrm{s}^{2}$ sampai $956,75 \mathrm{~cm} / \mathrm{s}^{2}$ yaitu di Kecamatan Padang Selatan dan Padang Barat dan mengecil ke arah timur Kota Padang. Intensitas gempa Kota Padang akibat gempa intraplate adalah sekitar IX MMI. Dampak gempa dengan intensitas IX menimbulkan kondisi kerusakan yang parah yang ditandai dengan adanya gejala kerusakan pada struktur bangunan, dan muncul gejala likuifaksi di area alluvial atau pasir.
\end{abstract}

Kata kunci : Gempa bumi, Intensitas, MMI, Percepatan tanah, interplate, intraplate

\section{PENDAHULUAN}

Wilayah kota Padang secara regional merupakan bagian yang tidak terpisahkan dari Sistem Sesar Besar Sumatera (Sumatera Great Fault System). Sesar Semangko yang terdapat pada bagian tengah Pulau Sumatera dan palung laut di barat Pulau Sumatera mengapit wilayah Kota Padang dan sekaligus merupakan pusat terjadinya kegiatan tektonik di wilayah ini (Isra, 2010). Kondisi ini menyebabkan Kota Padang menjadi 
kawasan rawan bencana dengan sumber gempa merusak. Kawasan pemukiman yang berdekatan dengan sumber gempa bumi merupakan kawasan yang sangat rawan bencana. Langkah langkah mitigasi yang strategis perlu diupayakan untuk mengurangi atau memperkecil dampak kerugian atau kerusakan yang dapat ditimbulkan oleh bencana (Bakornas PBP, 2002).

Usaha memprediksi kapan, dimana dan berapa kekuatan gempa bumi sampai saat ini belum berhasil dengan tepat, maka usaha paling baik dalam mengantisipasi bencana gempa bumi adalah dengan melakukan mitigasi bencana gempa bumi. Salah satu upaya mitigasi bencana gempa bumi adalah melakukan kajian rencana tata ruang dan wilayah (RTRW) di Kota Padang. Untuk itu diperlukan sebuah peta percepatan getaran tanah maksimum. Peta ini menggambarkan tingkat kerawanan terhadap bencana gempa bumi untuk keperluan RTRW maupun konstruksi bangunan tahan gempa.

Setiap gempa yang terjadi akan menimbulkan satu nilai percepatan tanah pada suatu tempat. Nilai percepatan tanah yang akan diperhitungkan dalam perencanaan bangunan adalah percepatan tanah maksimum. Nilai ini akan menunjukkan resiko kerusakan yang akan ditimbulkan terhadap bangunan. Nilai percepatan tanah sangat dibutuhkan untuk menyesuaikan kekuatan bangunan yang akan dibangun pada daerah tersebut (Sunarjo,dkk., 2010).

Untuk mengukur besarnya nilai percepatan tanah dapat menggunakan alat pengukur akselerograf dan pendekatan secara empiris. Penempatan akselerograf pada beberapa titik tertentu saja akan menghasilkan pengukuran tanah hanya pada daerah tertentu juga. Sedangkan pendekatan secara empiris dapat memberikan gambaran secara umum untuk percepatan tanah maksimum sesuai titik yang dibutuhkan (Ibrahim dan Subardjo, 2003). Pendekatan empiris disesuaikan dengan kondisi tektonik dari daerah pengamatan. Salah Pendekatan empiris yang digunakan dalam mengestimasi percepatan tanah suatu wilayah adalah Rumusan Si and Midorikawa.

Rumusan Si and Midorikawa dibuat berdasarkan analisis kecepatan dan percepatan tanah maksimum dari 21 gempa bumi yang terjadi di Jepang. Ditinjau dari kondisi tektonik, bentuk patahan lempeng di Jepang hampir mirip dengan bentuk patahan lempeng di Kepulauan Mentawai. Sumber gempa bumi di Jepang juga berada di zona subduksi dan zona sesar geser.

Pada penelitian ini, rumusan empiris Si and Midorikawa digunakan untuk memetakan nilai percepatan tanah maksimum sebagai parameter kekuatan getaran tanah akibat gempa bumi di beberapa titik di Kota Padang dan membuat peta perceparan tanah maksimum dan Intensitas gempa bumi Kota Padang dan melakukan analisis dampaknya. 


\section{DATA DAN METODE PENELITIAN}

\subsection{Data}

Data yang digunakan dalam penelitian ini adalah data sekunder episenter dan hiposenter gempa bumi yang terjadi pada wilayah interplate dan intraplate segmen Mentawai dari tahun 1976 sampai 2016 dengan kekuatan $\geq 5$ SR dan kedalaman maksimal $70 \mathrm{~km}$. Data ini didapatkan dari situs United States Geological Survey (USGS).

\subsection{Metode Penelitian}

Untuk mengestimasi nilai percepatan tanah maksimum di Kota Padang akibat gempa yang terjadi pada tahun 1976 sampai 2016 dengan menggunakan rumusan $\mathrm{Si}$ and Midorikawa dilakukan dengan tahap-tahap sebagai berikut :

1. Mengumpulkan data sekunder gempa bumi yang terjadi pada wilayah Mentawai dari tahun 1976 sampai 2016

2. Membagi daerah penelitian dengan jarak $0,02^{\circ}$

3. Menghitung jarak antara koordinat episenter ke masing - masing koordinat daerah perhitungan, sehingga diperoleh jarak episenter. Jarak episenter bisa diketahui dengan menggunakan Persamaan (2.1) :

dengan :

$$
\square^{2} \square \tilde{x}_{2} \quad x_{1}^{2} \ldots \tilde{y}_{2} y_{k}^{2}
$$

$x_{1}=$ lintang daerah perhitungan ( derajat)

$y_{1}=$ bujur daerah perhitungan (derajat)

$x_{2}=$ lintang episenter gempa (derajat)

$y_{2}=$ bujur episenter gempa (derajat)

2. Menghitung jarak hiposenter dengan Persamaan (2.2):

dengan :

$$
R^{2}=\Delta^{2}+h^{2}
$$

$R=$ jarak hiposenter $(\mathrm{km})$

$\Delta=$ jarak episenter $(\mathrm{km})$

$h=$ kedalaman $(\mathrm{km})$

3. Menghitung nilai percepatan tanah maksimum dengan menggunakan rumus empiris Si and Midorikawa untuk di tiap-tiap titik grid

4. Menentukan nilai maksimum percepatan tanah dari semua data gempa di setiap titik.

5. Mengkonversi nilai Peak Ground Acceleration (PGA) ke skala Modified Mercalli Intensity $(M M I)$, untuk menunjukkan skala intensitas dengan menggunakan rumusan empiris Murphy \& O’Brien pada Persamaan 2.3. 
$\mathrm{MMI}=2,86 \log (\mathrm{PGA})+1,24$

dengan $M M I$ adalah skala intensitas dan PGA adalah Peak Ground Acceleration (gal).

6. Membuat peta intensitas dan percepatan tanah maksimum kota Padang dengan menggunakan software Surfer dan Arcgis.

7. Menganalisis nilai intensitas dan percepatan tanah maksimum Kota Padang dari pemetaan yang telah dilakukan

\section{HASIL DAN DISKUSI}

\subsection{Percepatan Tanah Maksimum Kota Padang}

Nilai percepatan tanah dilakukan pada setiap grid dengan membagi daerah penelitian sebesar $0,02^{\circ}$ sehingga diperoleh 208 titik perhitungan yang dapat dilihat pada Gambar 3.1. Pada setiap titik dilakukan penghitungan nilai percepatan tanah dari 106 data gempa yang berasal dari wilayah interplate dan 15 data gempa yang berasal dari wilayah intraplate segmen Mentawai. Hal ini sesuai dengan kriteria pemilihan data gempa dari tahun 1976 sampai 2016 dengan magnitudo $\geq 5$ SR yang terjadi di wilayah interplate dan intraplate di segmen ini.

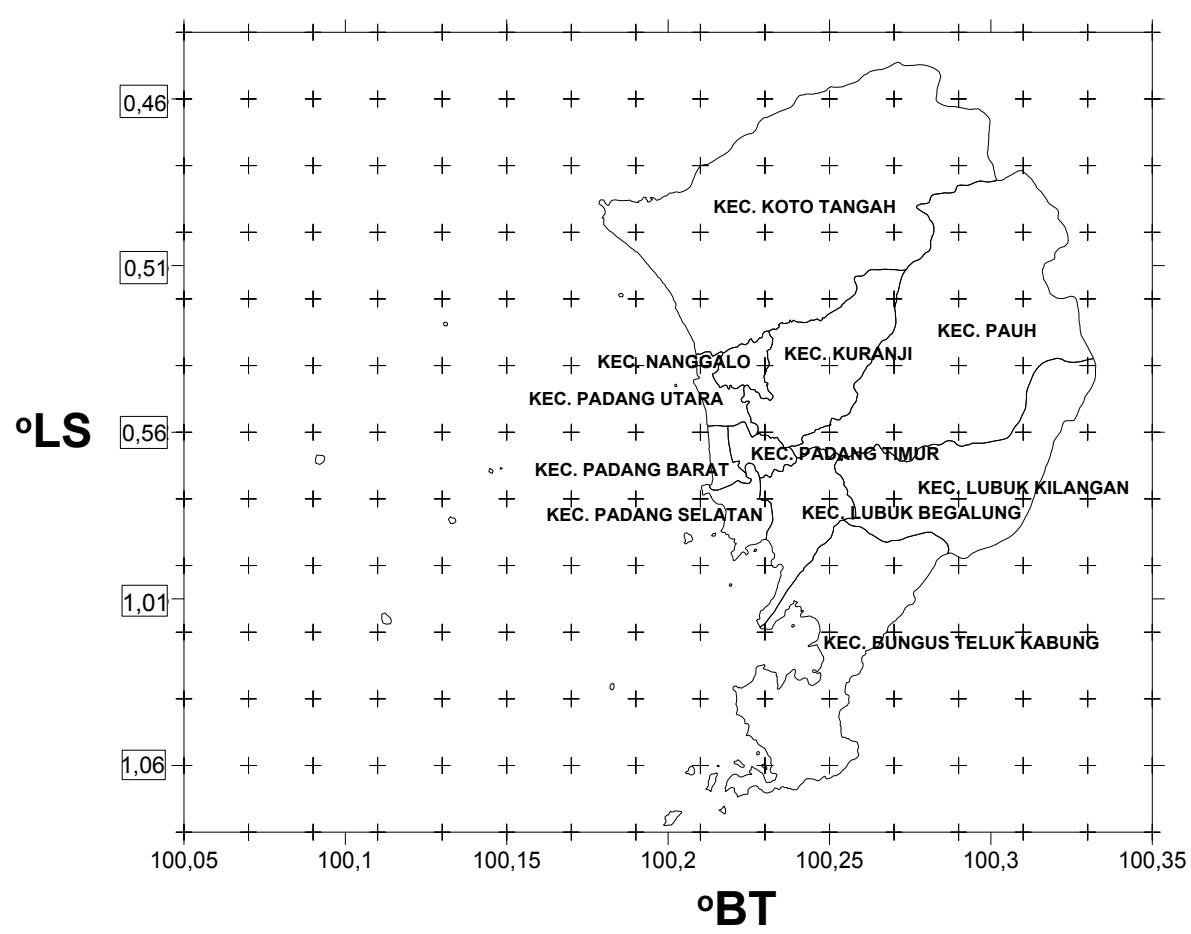

Gambar 1. Grid Kota Padang 
Penelitian dilakukan untuk memperoleh nilai percepatan tanah maksimum untuk 208 titik daerah penghitungan di wilayah kota Padang dengan kondisi grid pemetaan seperti pada Gambar 1. Percepatan tanah dibedakan berdasarkan data gempa dari gempa bumi wilayah interplate dan intraplate Segmen Mentawai.

\subsubsection{Percepatan Tanah Maksimum Kota Padang dengan Episenter Gempa Interplate di Wilayah Mentawai}

Berdasarkan penelitian yang dilakukan, diperoleh nilai percepatan tanah maksimum dari gempa di wilayah interplate untuk 208 titik daerah penghitungan di wilayah kota Padang untuk peta grid pada Gambar 1. Jumlah data gempa yang digunakan untuk segmen interplate adalah 99 data gempa dengan magnitudo lebih besar atau sama dengan $5 \mathrm{M}_{\mathrm{w}}$ dengan magnitudo gempa terbesar adalah $6,7 \mathrm{M}_{\mathrm{w}}$.

Berdasarkan data yang diperoleh, dihasilkan peta percepatan tanah maksimum Kota Padang dengan episenter wilayah interplate Segmen Mentawai seperti pada Gambar 2

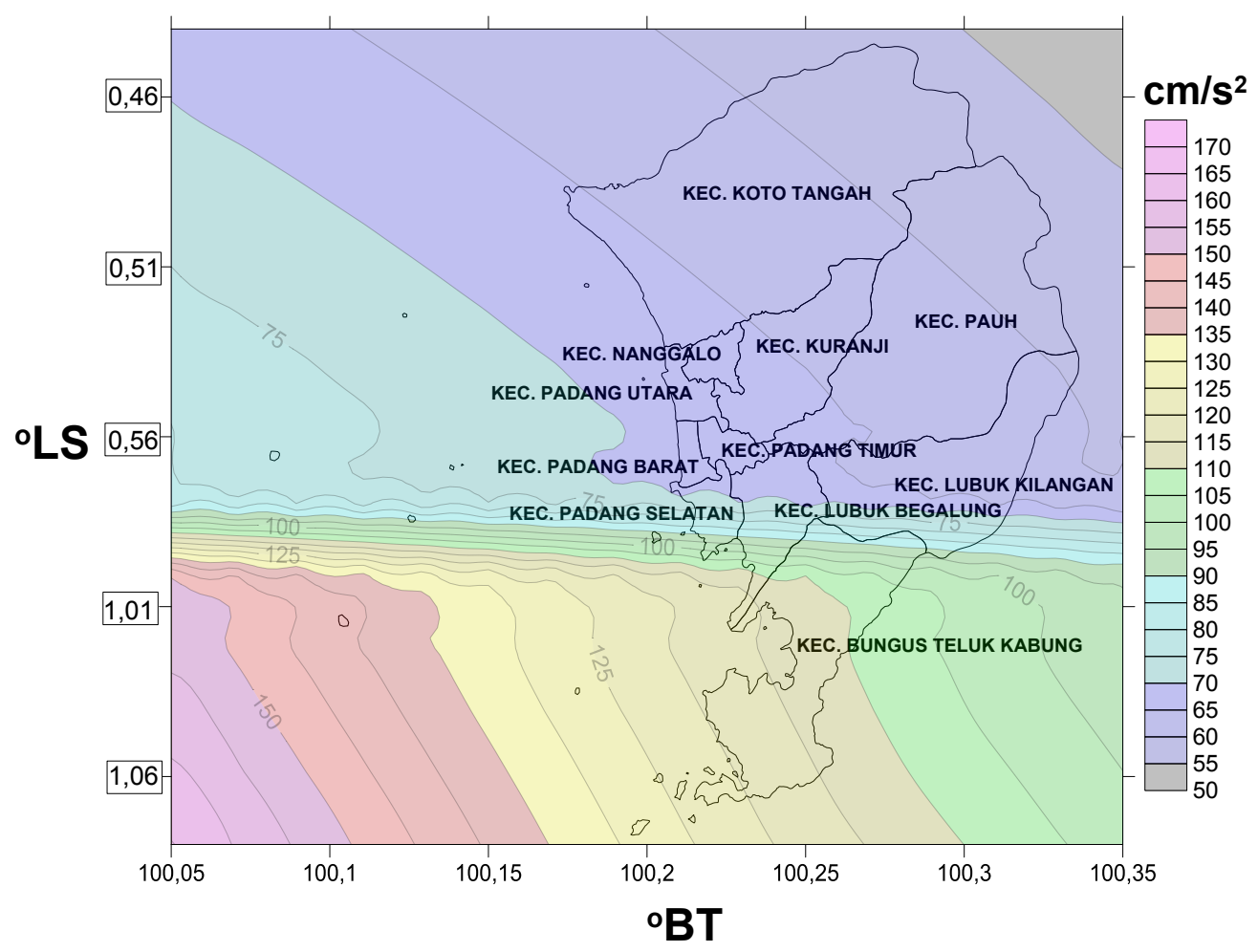

Gambar 2. Peta percepatan tanah maksimum Kota Padang dengan episenter wilayah interplate Segmen Mentawai

JURNAL ILMU FISIKA (JIF), VOL 9 NO 2, SEPTEMBER 2017 
Berdasarkan Gambar 2 dapat diketahui nilai percepatan tanah maksimum terbesar di Kota Padang akibat gempa di wilayah interplate Segmen Mentawai berkisar dari 57,89 $\mathrm{cm} / \mathrm{s}^{2}$ sampai $119,69 \mathrm{~cm} / \mathrm{s}^{2}$. Kecamatan dengan percepatan tanah maksimum akibat gempa di wilayah interplate adalah Kecamatan Bungus Teluk Kabung yaitu berkisar antara $106,21 \mathrm{~cm} / \mathrm{s}^{2}$ sampai $119,69 \mathrm{~cm} / \mathrm{s}^{2}$. Dengan rata rata percepatan tanah maksimum terbesar berada di arah selatan kecamatan Bungus yang mengarah ke Kabupaten Pesisir Selatan. Kecamatan dengan percepatan tanah maksimum terkecil akibat gempa wilayah interplate berada di wilayah Kecamatan Koto Tengah yaitu sebesar $57,89 \mathrm{~cm} / \mathrm{s}^{2}$. Sesuai dengan pemetaan percepatan tanah akibat gempa wilayah interplate Segmen Mentawai maka wilayah paling rawan adalah Kecamatan Bungus Teluk Kabung, diikuti dengan wilayah kedua yaitu Kecamatan Padang Selatan dan Kecamatan Lubuk Begalung. Wilayah dengan percepatan tanah terkecil berada di kelompok wilayah ketiga yang meliputi Kecamatan Koto Tengah, Kecamatan Pauh, Kecamatan Kuranji, Nanggalo, Lubuk Kilangan, Kecamatan Padang Timur, Kecamatan Padang Utara, dan Kecamatan Padang Barat.

\subsubsection{Percepatan Tanah Maksimum Kota Padang dengan Episenter Gempa Wilayah Intraplate di Segmen Mentawai}

Berdasarkan penelitian yang dilakukan, diperoleh nilai percepatan tanah maksimum dari gempa di wilayah intraplate untuk 208 titik daerah penghitungan di wilayah Kota Padang untuk peta grid pada Gambar 1. Jumlah data gempa yang digunakan untuk segmen intraplate adalah adalah 15 data gempa dengan magnitudo lebih besar atau sama dengan $5 \mathrm{M}_{\mathrm{w}}$ dengan gempa terbesar $7,6 \mathrm{M}_{\mathrm{w}}$.

Berdasarkan data yang diperoleh, dihasilkan peta percepatan tanah maksimum Kota Padang dengan episenter segmen intraplate wilayah Mentawai seperti pada Gambar 3. Dari Gambar 3 dapat diketahui nilai percepatan tanah maksimum terbesar di Kota Padang akibat gempa di segmen intraplate wilayah Mentawai berkisar antara sebesar 830,38 $\mathrm{cm} / \mathrm{s}^{2}$ sampai $956,75 \mathrm{~cm} / \mathrm{s}^{2}$. Kecamatan dengan percepatan tanah maksimum akibat gempa wilayah intraplate adalah Kecamatan Padang Selatan dengan percepatan maksimum 956,75 cm/ $\mathrm{s}^{2}$, kemudian diikuti dengan Kecamatan Padang Barat, Kecamatan Padang Timur, Kecamatan Padang Utara, Kecamatan Lubuk Begalung, sebagian Kecamatan Koto Tengah, Kecamatan Lubuk Kilangan. Percepatan tanah mengecil ke arah Kecamatan Kuranji, Pauh, Lubuk Kilangan dan sebagian Kecamatan Lubuk Begalung dan Kecamatan Bungus. Secara umum percepatan tanah maksimum kota Padang terbagi tiga wilayah seperti pada Gambar 3 yaitu wilayah 1 Kecamatan Padang Utara, Padang Selatan, Padang Timur, Padang Barat, Nanggalo dan sebagian Lubuk Begalung. Wilayah 2 meliputi Sebagian Kecamatan Koto tengah, Kecamatan Kuranji, sebagian Kecamatan Pauh, Kecamatan Nanggalo, Kecamatan Lubuk Kilangan dan sebagian Kecamatan Lubuk Begalung. Wilayah 3 merupakan wilayah dengan percepatan tanah terkecil terdiri dari Kecamatan Bungus dan Kecamatan Pauh yang berbatasan dengan Kabupaten Solok. 


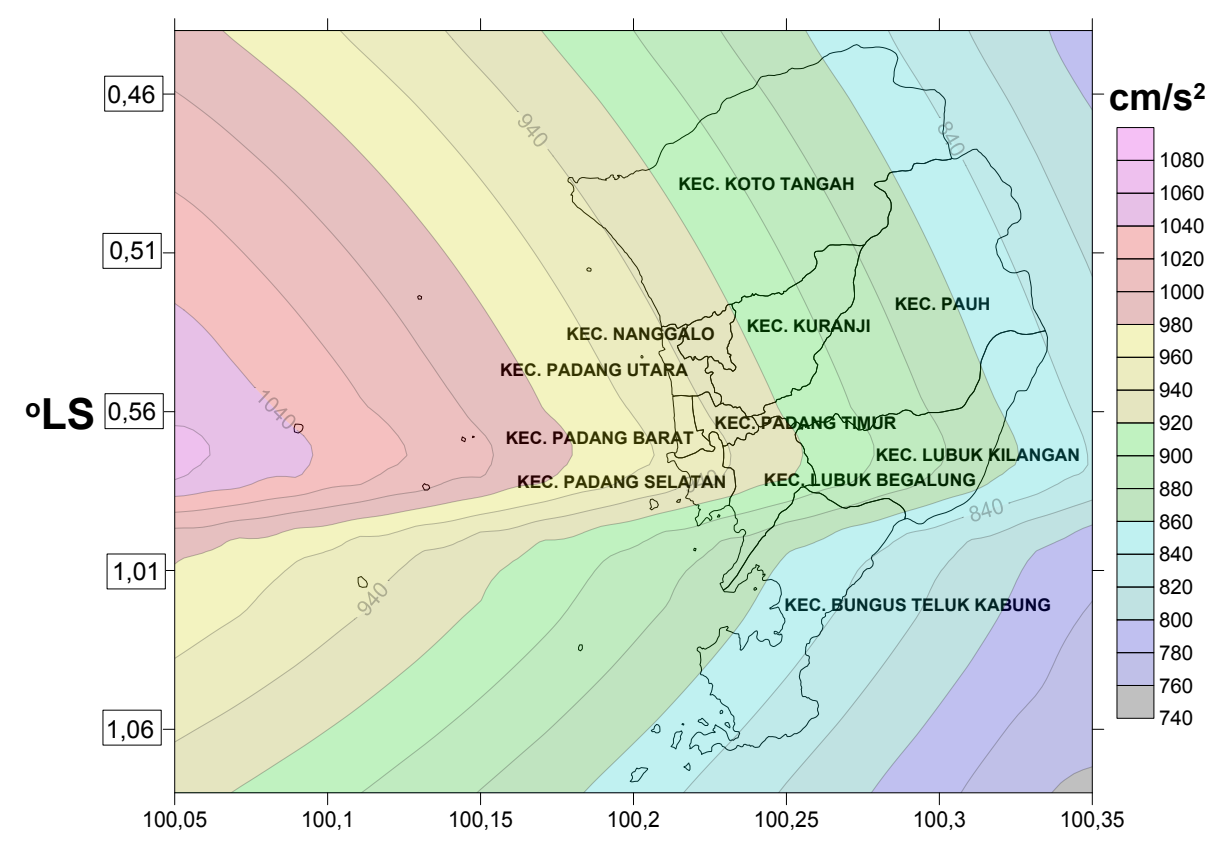

Gambar 3 Peta percepatan tanah maksimum Kota Padang dengan episenter segmen intraplate wilayah Mentawai

\subsection{Intensitas Gempa Kota Padang}

\subsubsection{Intensitas Gempa Kota Padang dengan dengan Episenter Gempa Wilayah Interplate di Segmen Mentawai}

Berdasarkan nilai intensitas gempa wilayah interplate segmen Mentawai yang didapatkan maka dapat dilihat pemetaan intensitas Kota Padang pada Gambar 4. Pada Gambar 4 ini dapat dilihat intensitas gempa Kota Padang akibat gempa wilayah interplate Segmen Mentawai yang berkisar antar 6 sampai 7 skala MMI. Intensitas 7 MMI berada di sekitar Kecamatan Bungus, dan intesitas gempa mengecil ke arah Kecamatan Pauh. Gejala yang ditimbulkan berupa gempa yang dapat dirasakan oleh semua orang dan sudah menimbulkan kerusakan ringan berupa keretakan pada bangunan. Benda-benda yang digantung bergoyang dan jendela kaca akan bergetar. 


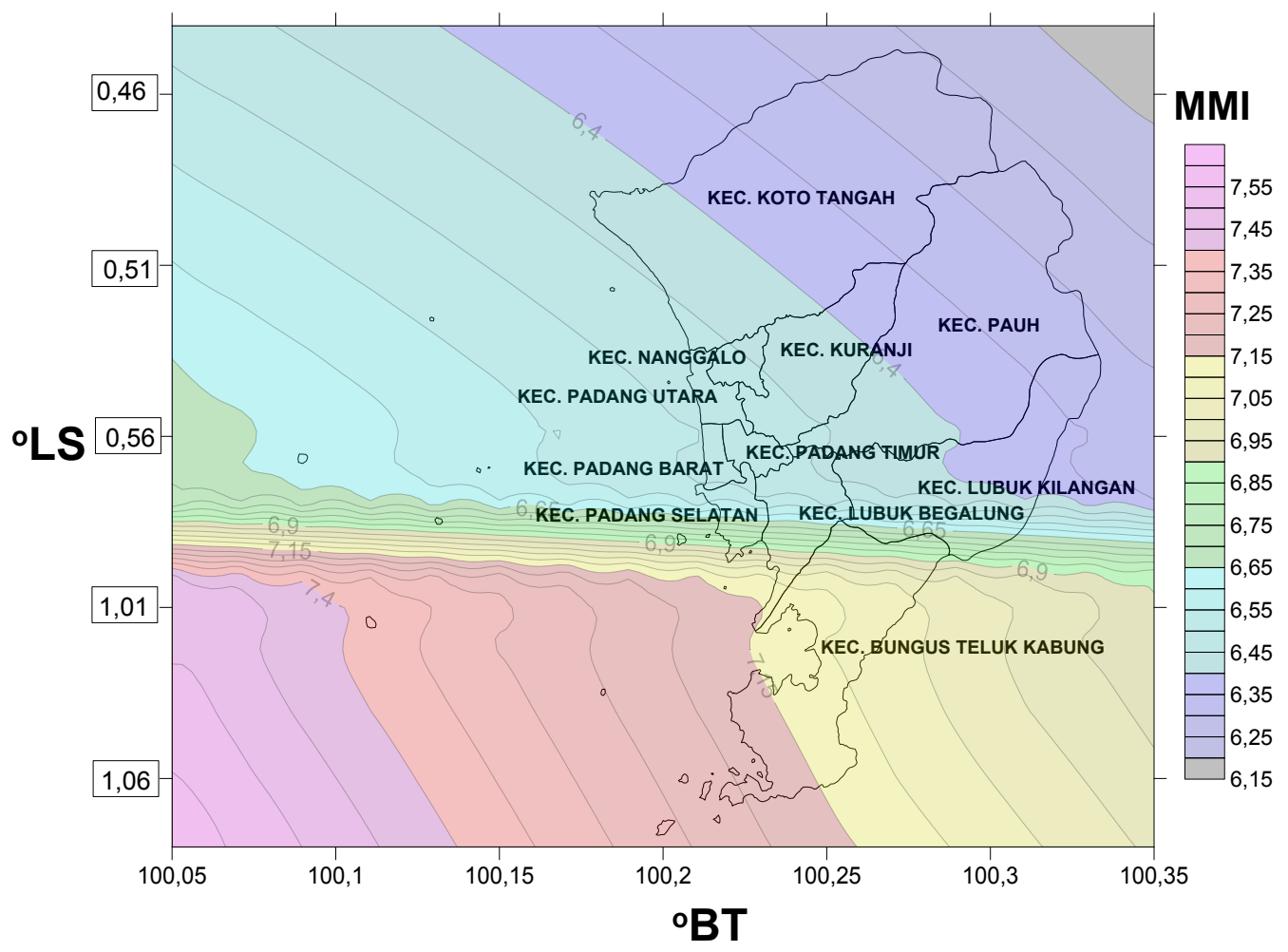

Gambar 4. Peta Intensitas Kota Padang dengan episenter segmen interplate wilayah Mentawai

\subsubsection{Intensitas Gempa Kota Padang dengan dengan Episenter Gempa Wilayah Intraplate di Segmen Mentawai}

Berdasarkan nilai intensitas gempa Wilayah intraplate di segmen Mentawai yang didapatkan maka dapat dilihat pemetaan intensitas Kota Padang seperti pada Gambar 5. Dari Gambar 5 dapat dilihat bahwa intensitas gempa Kota Padang akibat gempa intraplate adalah berkisar IX MMI dan merata di seluruh wilayah kota Padang dengan intensitas paling besar di wilayah Kecamatan Padang Barat dan mengecil ke arah Kecamatan Pauh. Dampak gempa dengan intensitas IX menimbulkan kondisi kerusakan yang parah yang ditandai dengan adanya gejala kerusakan pada struktur bangunan, dan muncul gejala likuifaksi di area alluvial atau pasir. 


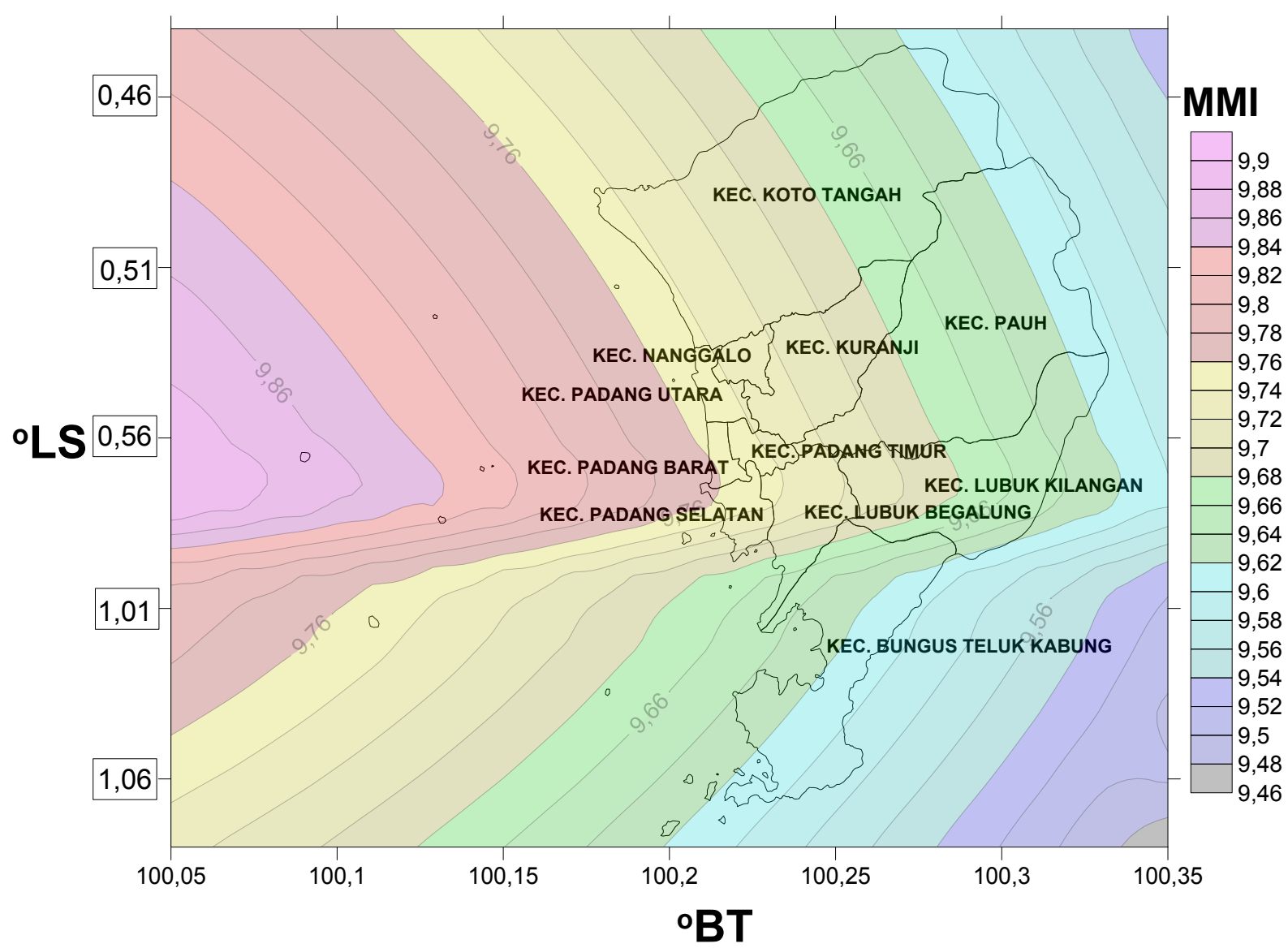

Gambar 5 Peta Intensitas Kota Padang dengan episenter wilayah intraplate segmen Mentawai

\subsection{Perbandingan Dampak Gempa wilayah Interplate dan Intraplate Segmen Mentawai terhadap Percepatan tanah dan Intensitas Gempa Kota Padang}

Nilai percepatan tanah maksimum dan intensitas gempa Kota Padang dengan episenter gempa pada wilayah intraplate Segmen Mentawai memiliki nilai yang lebih tinggi dibandingkan episenter pada wilayah interplate segmen Mentawai. Hal ini disebabkan oleh beberapa hal diantaranya gempa yang berasal dari wilayah intraplate memiliki kekuatan yang lebih besar. Selain itu juga dipengaruhi oleh kedalaman gempa yang lebih dangkal dan jarak episenter yang lebih dekat. 
Dari nilai percepatan tanah maksimum dan intensitas Kota Padang yang diperoleh dapat dibandingkan dampak akibat gempa yang berasal dari wilayah interplate dan intraplate Segmen Mentawai. Gempa yang bersumber dari wilayah intraplate Segmen Mentawai dapat menimbulkan kerusakan yang serius yang ditandai dengan kerusakan struktur bangunan dan menimbulkan gejala likuifaksi dengan kerusakan yang hampir merata di seluruh wilayah Kota Padang dengan intensitas gempa sekitar IX MMI. Sedangkan dampak gempa yang bersumber dari wilayah interplate segmen Mentawai di kota Padang adalah gempa yang dapat dirasakan dan menimbulkan kerusakan ringan berupa keretakan pada bangunan dengan intensitas gempa sekitar VI - VII skala MMI. Kerusakan yang ditimbulkan oleh gempa wilayah interplate lebih ringan jika dibandingkan dengan kerusakan gempa akibat gempa yang berasal dari wilayah intraplate segmen Mentawai.

\section{KESIMPULAN}

Berdasarkan hasil penelitian didapatkan kesimpulan sebagai berikut :

1. Nilai percepatan tanah maksimum terbesar di Kota Padang akibat gempa di wilayah interplate segmen Mentawai berkisar dari $57,89 \mathrm{~cm} / \mathrm{s}^{2}$ sampai $119,69 \mathrm{~cm} / \mathrm{s}^{2}$. Kecamatan dengan percepatan tanah maksimum akibat gempa wilayah ini adalah Kecamatan Bungus Teluk Kabung yaitu berkisar antara 106,21 cm/s $\mathrm{s}^{2}$ sampai 119,69 $\mathrm{cm} / \mathrm{s}^{2}$.

2. Nilai percepatan tanah maksimum terbesar di Kota Padang akibat gempa di wilayah intraplate segmen Mentawai berkisar antara sebesar $830,38 \mathrm{~cm} / \mathrm{s}^{2}$ sampai 956,75 $\mathrm{cm} / \mathrm{s}^{2}$. Kecamatan dengan percepatan tanah maksimum akibat gempa wilayah ini adalah Kecamatan Padang Selatan dengan percepatan maksimum 956,75 cm/s kemudian diikuti dengan Kecamatan Padang Barat, Kecamatan Padang Timur, Kecamatan Padang Utara, Kecamatan Lubuk Begalung, sebagian Kecamatan Koto Tengah, Kecamatan Lubuk Kilangan. Percepatan tanah mengecil ke arah kecamatan Kuranji, Pauh, Lubuk Kilangan dan sebagian sebagian Kecamatan Lubuk Begalung dan Kecamatan Bungus.

3. Intensitas gempa Kota Padang akibat gempa wilayah interplate Segmen Mentawai berkisar antara VI sampai VII skala MMI. Intensitas VII MMI berada di sekitar Kecamatan Bungus, dan intesitas gempa mengecil ke arah Kecamatan Pauh.

4. Intensitas gempa Kota Padang akibat gempa di wilayah intraplate Segmen Mentawai adalah berkisar IX MMI dan merata di seluruh wilayah kota Padang dengan intensitas paling besar di wilayah Kecamatan Padang Barat dan mengecil ke arah Kecamatan Pauh. Kondisi dengan intensitas IX Dampak gempa dengan intensitas IX menimbulkan kondisi kerusakan yang parah yang ditandai dengan adanya gejala kerusakan pada struktur bangunan, dan muncul gejala likuifaksi di area alluvial atau pasir. 


\section{UCAPAN TERIMA KASIH}

Penulis berterima kasih kepada pihak FMIPA Unand yang telah mendanai penelitian ini melalui Dana PNBP FMIPA Unand sesuai dengan kontrak Penelitian Nomor : 01/UN.15.03.D/PPFMIPA/2017 Tahun anggaran

\section{DAFTAR PUSTAKA}

1. Ardiansyah, S., 2010, Energi Potensial Gempa Bumi di Kawasan Segmen Mentawai Sumatera Barat $\left(0.5^{\circ} \mathrm{LS}-4.0^{\circ} \mathrm{LS}\right.$ dan $\left.100^{\circ} \mathrm{BT}-104^{\circ} \mathrm{BT}\right)$, Jurnal PSJ, Vol.2, No.1, BMKG Bengkulu.

2. Bakornas, PBP., 2002, Arahan Kebijakan Mitigasi Bencana Perkotaan Di Indonesia, Badan Koordinasi Nasional Penanggulangan Bencana dan Penanganan Pengungsi (BAKORNAS PBP), Jakarta.

3. BMKG, 2009, Fakta dan Data Gempa Padang, USGS, Bakosurtanal, Lapan.

4. Hadi, A.I., Suhendra, dan Manik, O.O., Pemetaan Gempa Bumi Berdasarkan Tingkat Keaktifan Gempa Di Provinsi Bengkulu Periode 1971-2011, Prosiding Semirata BKS PTN Barat, Bandar Lampung, 10 - 12 Mei 2013. hal.: 269-272, 2013.

5. Hadi, ArifIsmul., Muhammad Farid, dan Yulian Fauzi. (2012). Pemetaan Percepatan Getaran Tanah dan Indeks Kerentanan Seismik Akibat Gempabumi untuk Mendukung Rencana Tata Ruang dan Wilayah (RTRW) Kota Bengkulu. Bengkulu: Ilmu Fisika Universitas Bengkulu

6. Handewi Istiqorini, dan Daeng Sujito. (2014). Analisis Percepatan Getaran Tanah Maksimum dan Intensitas Gempabumi Tektonik wilayah Jawa Timur menggunakan metode Donovan. Malang: UNM

7. Ibrahim, G. dan Subarjo., 2004, Buku Seismologi, BMKG., Jakarta.

8. Isra, A.M., 2010, Kajian Kebencanaan. Jurnal Teknik Arsitektur, Vol 1, No 1, Universitas Bung Hatta.

9. Natawidjaja, D.H., 2007, Gempa Bumi dan Tsunami di Sumatera dan Upaya Untuk Mengembangkan Lingkungan Hidup Yang Aman Dari Bencana Alam, Laporan KHL, LIPI, Jakarta.

10. Natawidjaja, D. H., Sieh, K., Chlieh, M., Getzka, J., Suwargadi, B. W., Cheng, H., Edwards, R. L., Avouac, J. P., Ward, S. N., 2006, Source Parameters Of The Great Sumatran Megatrust Earthquakes of 1797 and 1833 Inferred From Coral Microatolls, Journal of Geophysical Research, Volume 111, American Geophysical Union.

11. Sieh, K., Bock, L. E., Taylor, F., Gans P., 1994, Active Tectonics of Sumatra, American Geophysical Union.

12. Si, H., Midorikawa, S., 2000, New Attenuation Relations For Peak Ground Accelerationion and Velocity Considering Effects of Fault Type And Site Condition, Japan

13. Sunarjo, Gunawan, M. T., Pribadi, S., 2010, Gempa Bumi Edisi Populer, BMKG., Jakarta. 